\title{
INTRATHORACIC TUMOURS OF CAROTID BODY TYPE (CHEMODECTOMA)
}

\author{
BY \\ J. D. BARRIE \\ From the Department of Pathology, Victoria Infirmary, Glasgow
}

(RECEIVED FOR PUBLICATION SEPTEMBER 1, 1960)

Intrathoracic tumours of carotid body type were identified by Lattes, who reported two cases in 1950. Since then only 10 further cases have been recorded, either because of their genuine rarity or from the infrequency of their recognition. A more complete knowledge of the normal distribution of chemoreceptor tissue should result from a study of such neoplasms, and it is therefore of more than academic interest that these should be classified correctly.

\section{TERMINOLOGY}

Gaffney (1953), in describing jugular bulb tumours, suggested that their structure was probably that of a chemoreceptor organ. Accepting LeCompte's (1948) view that tumours of the carotid body, which is the best defined and the most adequately studied of the chemoreceptor organs, reproduce in general the structure of the parent tissue, Gaffney further suggested that this group of neoplasms might be designated collectively by the term "receptoma."

Mulligan (1950) described as a chemodectoma " a neoplasm consisting of chemoreceptor (chemodector) cells, which are associated with the distribution of parasympathetic nerves and which originate either in the adventitia of blood vessels in structures intimately connected with afferent nerve fibres or which occur along the branches or in the ganglia of the glossopharyngeal and vagus nerves." Lattes and Waltner (1949) preferred "non-chromaffin paraganglioma," the designation "non-chromaffin" to distinguish this type of tumour from the paraganglioma of sympathetic nervous tissue. The term "paraganglion" had been used to include a number of diverse structures ranging from the adrenal medulla to the glomus coccygeum, but, in 1950, Lattes clarified the position with the following classification.
I True paraganglia (sympathetic)

(a) Adrenal medulla

(b) Chromaffin cell nests associated with the visceral sympathetic ganglia, especially along the thoraco-lumbar chain and the pelvic plexuses

Il Non-chromaffin paraganglia (parasympathetic)

(a) Carotid and aortic arch bodies

(b) Glomus jugulare

(c) Ganglion nodosum of vagus

(d) Ciliary body

(e) Miscellaneous: other less constant mediastinal chemoreceptors, isolated groups in the retroperitoneal area, groin, and thigh

III Carotid and aortic sinuses

IV Neuromyoarterial glomera

The carotid and aortic sinuses function as pressure receptors, and the neuromyoarterial glomera form well-defined groups which will not be considered further in the present paper. In addition to the different anatomical sites of the larger chemoreceptor organs other points of contrast between groups I and II are summarized in Table I.

TABLE I

\begin{tabular}{|c|c|}
\hline True Paraganglia & "Non-chromaffin" Paraganglia \\
\hline $\begin{array}{l}\text { Common embryological origin } \\
\text { with ganglion cells of the } \\
\text { sympathetic nervous system, } \\
\text { i.e., sympathochromaffin cells } \\
\text { of neural crest } \\
\text { Efferent sympathetic motor inner- } \\
\text { vation } \\
\text { Positive chromaffin reaction } \\
\text { Secretion of epinephrine or } \\
\text { similar substance }\end{array}$ & $\begin{array}{l}\text { Development associated with } \\
\text { paraganglia of cervical and } \\
\text { sacral parasympathetic nerves, } \\
\text { branchial arch vessels, and } \\
\text { large arteries of the limbs } \\
\text { Afferent sensory innervation, } \\
\text { probably parasympathetic } \\
\text { Usually negative chromaffin reac- } \\
\text { tion } \\
\text { No hormonal secretion }\end{array}$ \\
\hline
\end{tabular}


Willis (1953) stated that the chromaffin reaction varies not only from tumour to tumour but even from one part to another of the same growth, and consequently the term "non-chromaffin" paraganglioma is not ideal. It is, however, in common use and it can include histologically similar growths in the ganglion nodosum and glomus jugulare (Simpson and Dallachy, 1958), in the peritoneal tissues, groin, and thigh, and in other isolated sites (Smetana and Scott, 1951). Until the function of each of these different tissues is clarified it seems advisable to restrict the use of the term chemodectoma to tumours arising in organs of which the chemoreceptor activity is well established.

\section{ANATOMY}

The distribution of the known chemoreceptor tissue in the head, neck and chest is shown in Fig. 1. The aortic arch bodies number at least four: (1) Near the pulmonary end of the obliterated ductus arteriosus; (2) near the origin of the left coronary artery; (3) at the bifurcation of the innominate artery or lateral to the origin of the right subclavian artery; (4) on the anterolateral surface of the left side of the aortic arch near the root of the left subclavian artery.

As has already been stressed, not all the chemoreceptor tissue has been accurately charted, and according to Duncan and McDonald (1951) there is no reason why mediastinal tumours should always be situated precisely at the previously reported sites.

\section{Physiology}

The chemoreceptor organs are stimulated by oxygen lack, but not until the oxygen tension of the arterial blood reaches a relatively low level. They constitute a protection against anoxia, since the effect of oxygen lack on the respiratory centre is depression rather than stimulation. Schmidt, Dumke, and Dripps (1939) believe that the chemoreceptors do not play a role in the control of respiration under ordinary physiological conditions, but in anoxic states the reflex response of the chemoreceptors is of the highest importance. Comroe and Schmidt (1938) regard the chemoreceptor mechanism as a form of respiratory control which serves as a last line of defence against respiratory failure.

No convincing evidence that non-chromaffin paragangliomas are functional is as yet forthcoming, and it seems unlikely that assistance in diagnosis will be found in abnormalities of respiration or blood chemistry.

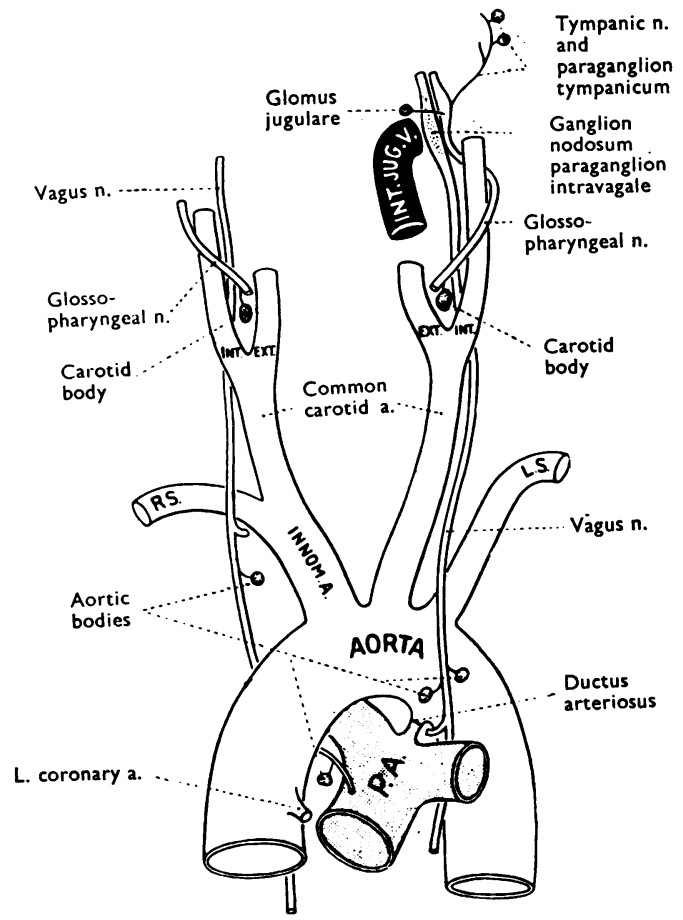

FIG. 1.-Diagram of chemoreceptor organs and their anatomical relationships. Modified from a diagram (Fig. 26, Cancer, 3, $667-694,1950)$ obtained through the courtesy of $R$. Lattes, after J. D. Boyd (Contr. Embryol. Carnegie Inst., 26, 1-31, 1937). By courtesy of Dr. P. M. LeCompte.

\section{CASE Reports}

CASE 1.-During necropsy on a 62-year-old man, who died of virus pneumonia in 1958, the tumour was discovered in the pericardium overlying the right auricle. It measured $3.5 \times 2.5 \times 1.5 \mathrm{~cm}$., the surface was nodular, and on section it was firm, rubbery, and yellowish brown; intersecting bands of fibrous tissue produced a lobulated appearance and a single area of degeneration was present.

The position of the tumour corresponded to that described by Davis and Randall (1954), and this raises the interesting possibility that this is yet another normal site for chemoreceptor tissue.

Microscopic Appearances.-The cells were loosely arranged in large masses subdivided by strands of fibrous tissue (Fig. 2). The vascularity of the growth was striking; the larger vessels ran in the supporting stroma, but a number of dilated sinusoids were present amongst the cells, as were innumerable small vascular spaces (Fig. 3): some of the walls of the latter showed early hyaline change. Generally the vessels were thin walled and were in close contact with the tumour cells, which tended to be grouped around the blood spaces or to form small alveolar structures; these were well demonstrated by silver impregnation, the 


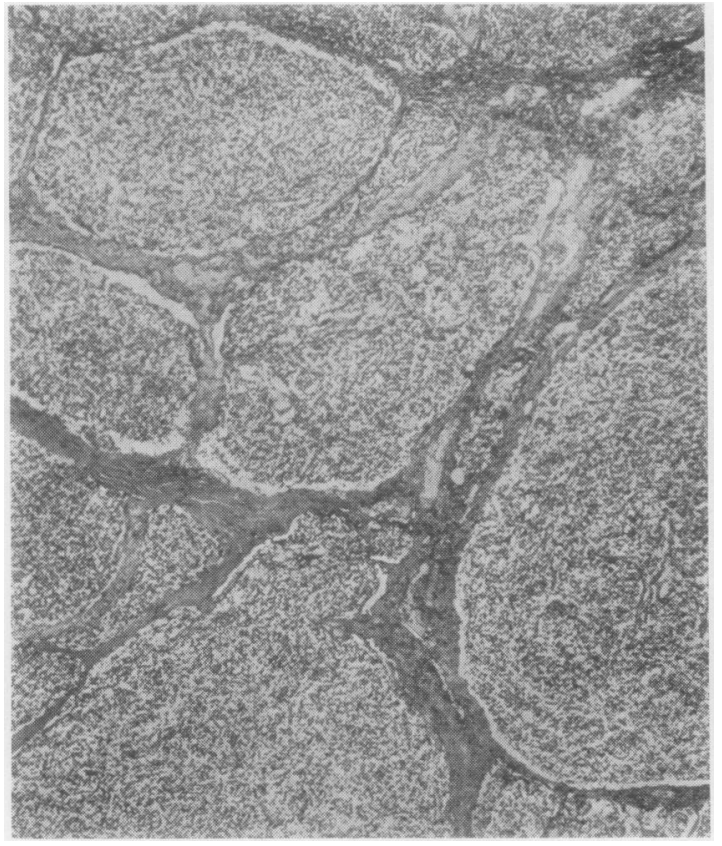

FIG. 2.-Case 1. Broad bands of collagen divide the tumour into large alveolar masses. Picro-Mallory, $\times 50$.

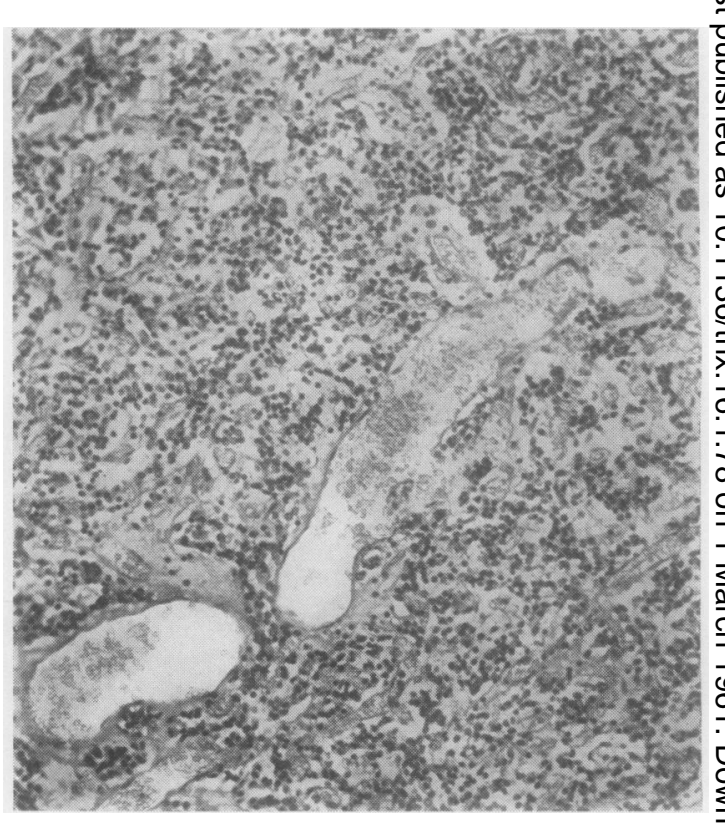

FIG. 3. Case 1. Two large sinusoids and many small blood vessels are visible. Picro-Mallory, $\times 130$.

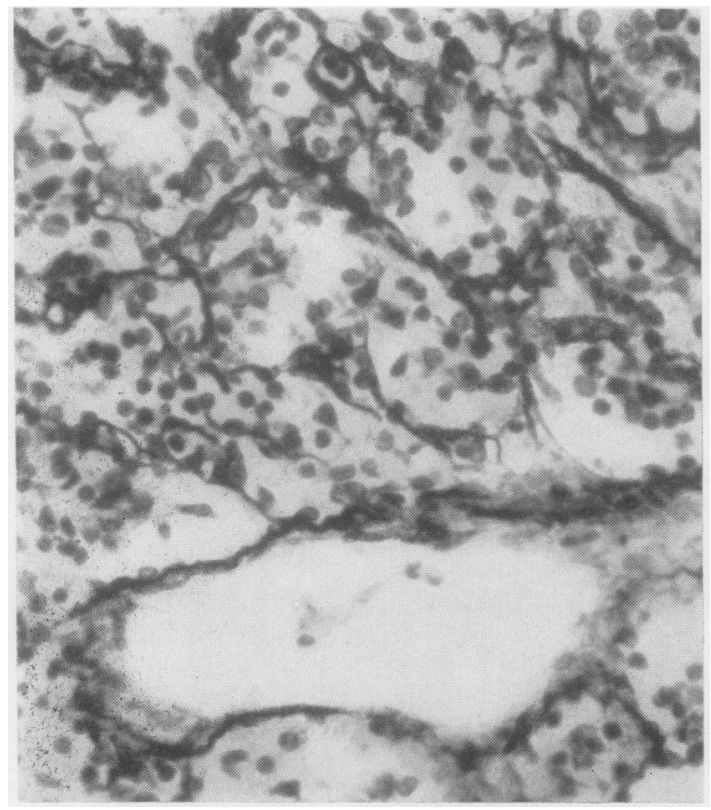

Fig. 4.-Case 1. Nests of cells enclosed by reticulin fibres. Reticulin, $\times 400$.

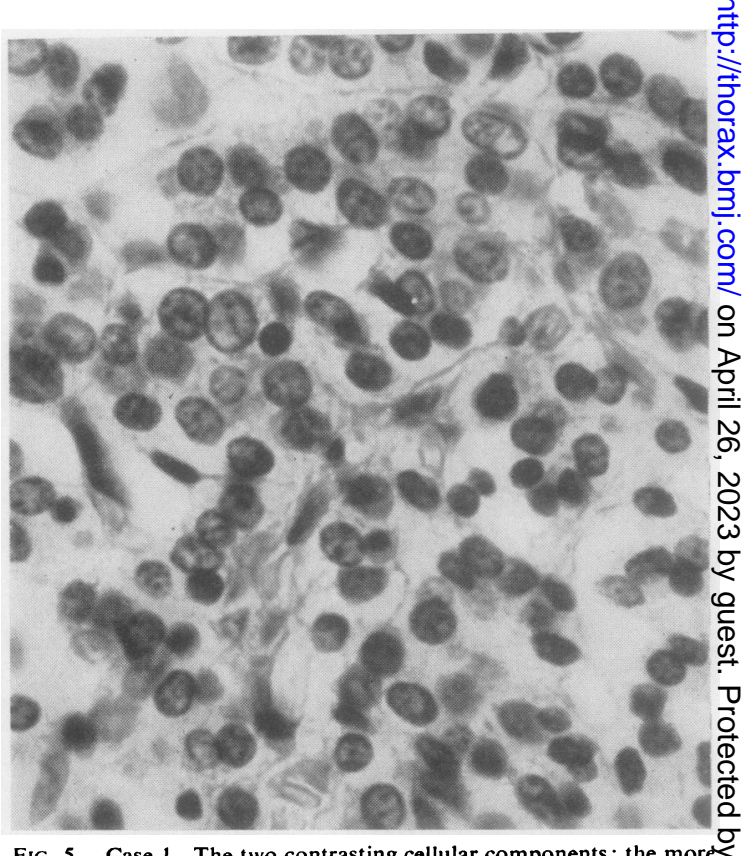

FIG. 5-Case 1. The two contrasting cellular components : the more numerous large vesicular cells and the small cells with uniforml: dense nuclei. Haematoxylin and eosin. $\times 800$. 


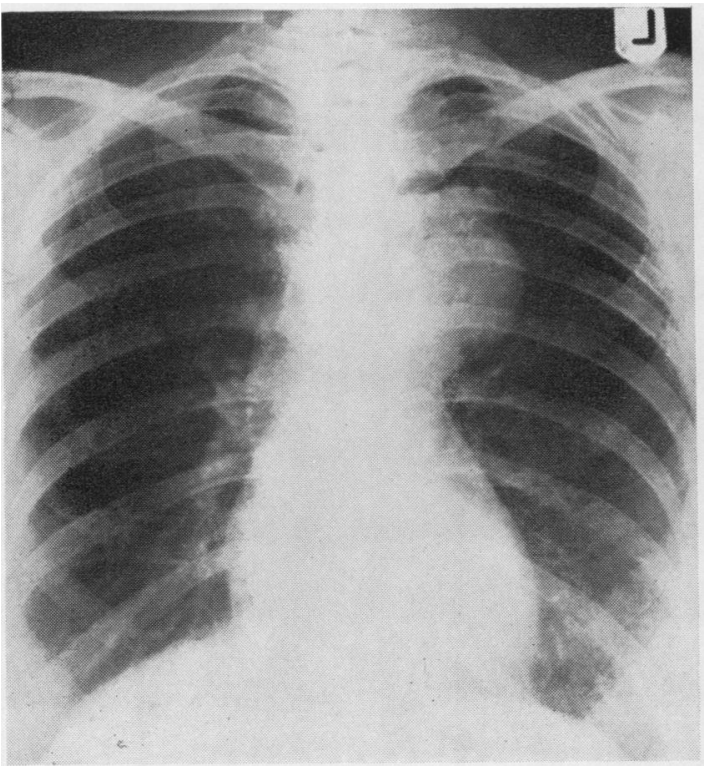

Fig. 6.-Case 2. Antero-posterior radiograph. Dense circumscribed shadow in left upper lung field.

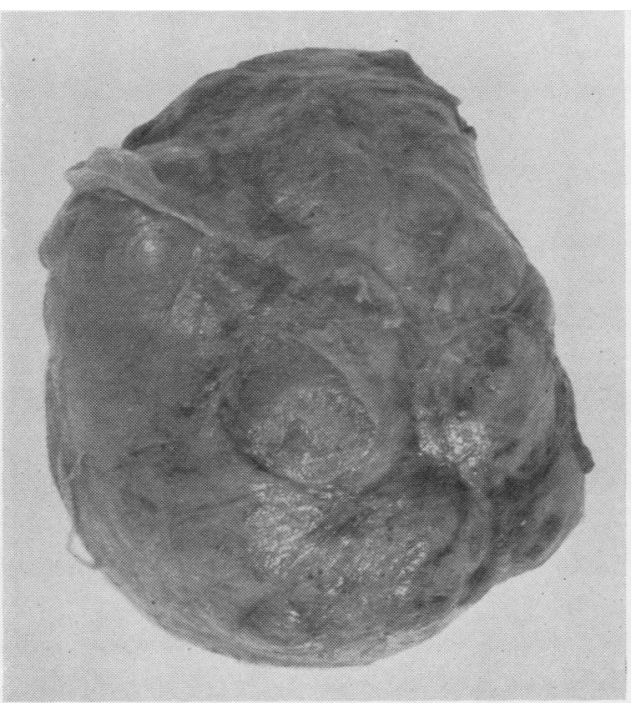

FIG. 8.-Case 2. The excised tumour enveloped in fine connective tissue. The lobulated structure is clear.

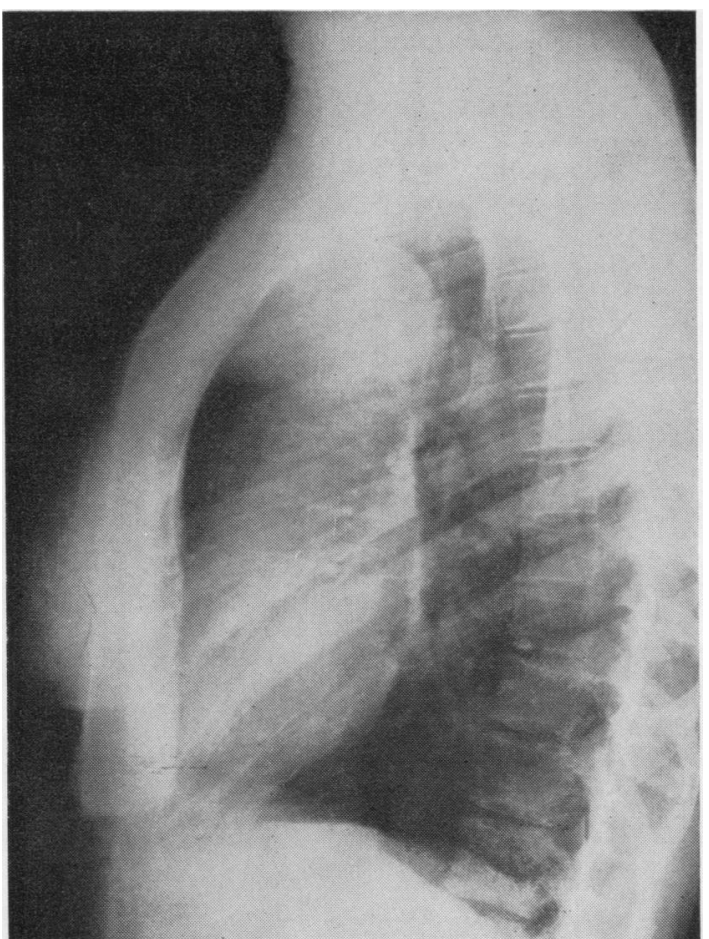

Fig. 7.-Case 2. Left lateral radiograph. Tumour visualized above the heart shadow, anterior to aorta.

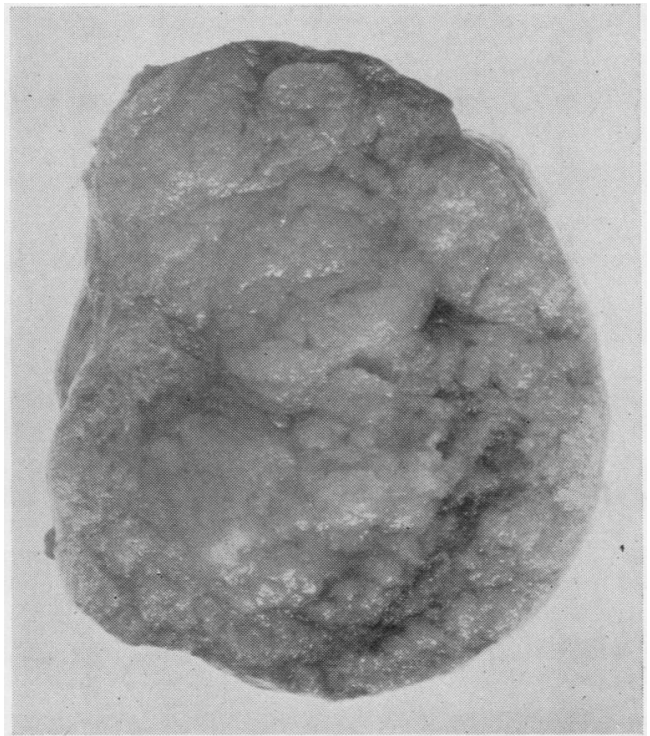

Fig. 9.-Case 2. The cut surface of the tumour. Strands of fibrous tissue separate the masses of neoplastic cells. 
reticulin fibres enclosing nests of 12 to 20 cells but not passing between the individual elements (Fig. 4). Two fairly distinct cell types were recognizable (Fig. 5 ), the larger with round or oval vesicular nucleus and a moderate amount of finely granular, faintly eosinophilic cytoplasm, the smaller characterized by its dense, almost pyknotic, nucleus which was often eccentrically placed. No mitoses or atypical cell forms were identified. Vascular invasion was absent, and no nerve fibres were seen. The degenerate area was composed of old blood clot, with deposits of haemosiderin, much of it phagocytosed.

CASE 2.-The second tumour was discovered incidentally in a woman of 51 years during a mass miniature radiography campaign in May, 1958. The patient's only relevant history was of an indigestionlike discomfort behind the sternum.

On admission to the Thoracic Unit at Mearnskirk Hospital on July 7, 1958, the peripheral blood picture

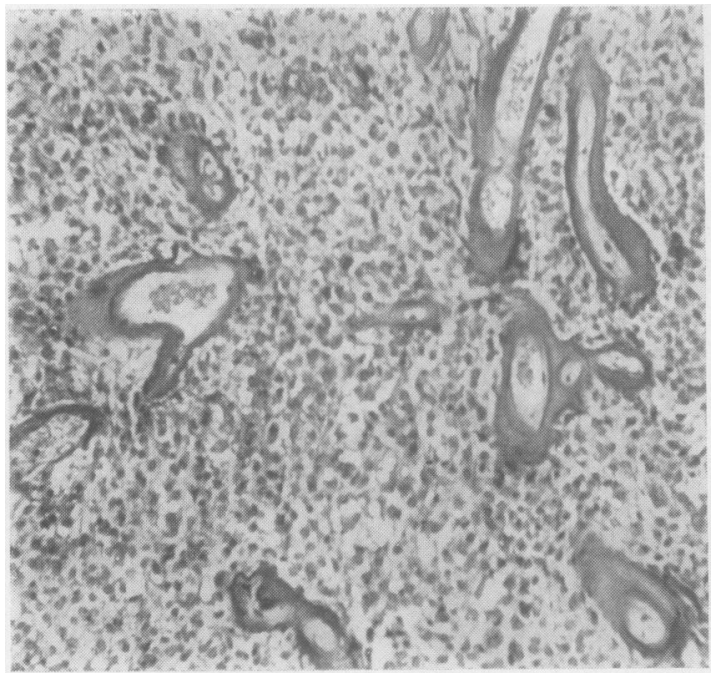

FIG. 10.-Case 2. Vascular pattern, well-marked hyalinization of vessel walls. Picro-Mallory, $\times 130$.

was normal, and the Wassermann and Meinicke reactions were negative. Mycobacterium tuberculosis was not isolated. Further chest radiographs showed a sharply defined shadow invading the left upper lung field from the mediastinum: it was not associated with the arch of the aorta (Figs. 6 and 7).

At operation in August a solid tumour (Figs. 8 and 9) was found lying anterior to the aorta and common carotid vessels and displacing the phrenic nerve laterally. It had no definite pedicle and was easily shelled out.

Within a week the lung had re-expanded, and the patient was discharged a fortnight later; her general condition and chest radiographs were satisfactory two months afterwards.

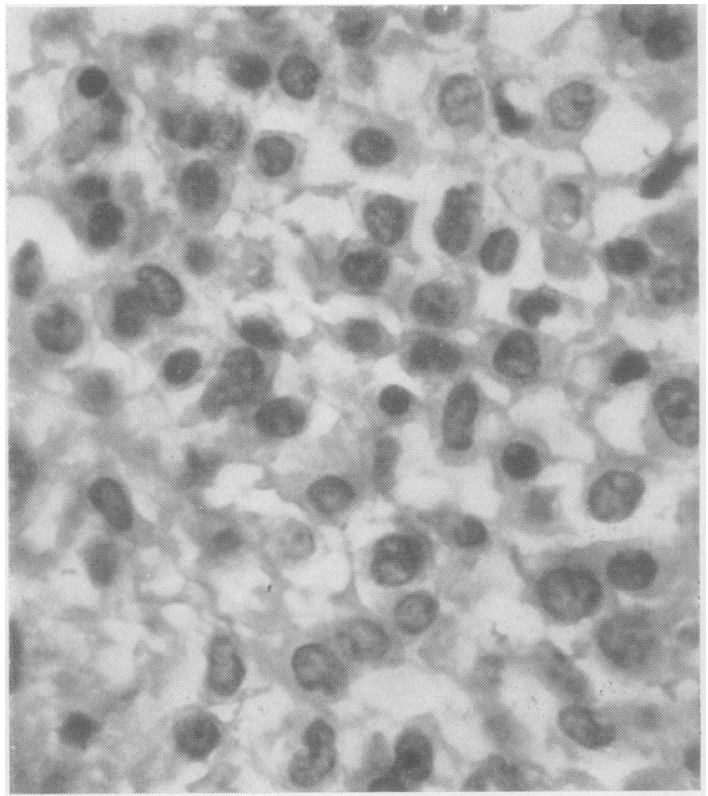

Fic. 11.-Case 2. The pattern is very similar to that in Case 1 and the two cell types are distinct. Picro-Mallory, $\therefore 800$.

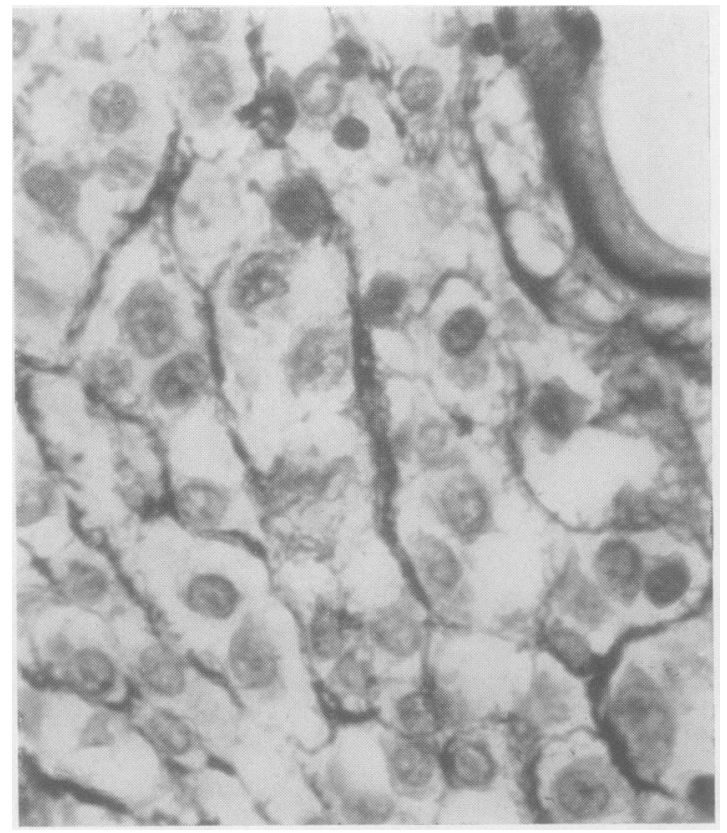

Fig. 12.-Case 2. Smaller cell nests enclosed by reticulin fibres. Reticulin $\times 800$ 
Grossly, the surgical specimen was a lobulated solid tumour measuring $7 \times 6 \times 5.5 \mathrm{~cm}$. It was a greyishbrown colour when fixed and section revealed firm, fleshy tissue flecked with areas of haemorrhage.

Microscopic Appearances. - The structure was essentially the same as that described in Case 1 ; the most obvious contrast, however, was the very advanced hyaline change (Fig. 10) which had occurred around the vessels. These appearances were very like those of Lattes' third case (Case 1, Table II) and they were considered to be later stages of the process noted in the first case now described. The two cell types were again present (Fig. 11) and the reticulin pattern was similar (Fig. 12), though the alveoli tended to be smaller than those of the first neoplasm; an origin from an aortic arch body was presumed.
The salient features of the two cases now reported and of 12 others traced in the literature are summarized in Table II.

\section{Differential Diagnosis}

This may be straighforward if the tumour arises at a recognized site, but may be difficult if the situation is unusual. To the naked eye these neoplasms are brown, tan, grey, or bluish-red, with a slightly lobulated surface. Commonly they are enveloped in fine connective tissue which is often very vascular. The value of immediate diagnosis by frozen section is stressed by McDonald, Aufderheide, and Fuller (1954), who

TABLE II

SALIENT FEATURES OF PRESENT SERIES AND OF CASES COLLECTED FROM THE LITERATURE

\begin{tabular}{|c|c|c|c|c|c|c|c|c|}
\hline \multicolumn{3}{|c|}{$\begin{array}{l}\text { Case, Sex, } \\
\text { and Age }\end{array}$} & Authors & $\begin{array}{l}\text { Site } \\
\text { of Tumour }\end{array}$ & $\begin{array}{c}\text { Size } \\
\text { and Weight }\end{array}$ & $\begin{array}{l}\text { Method } \\
\text { of Discovery }\end{array}$ & \multirow{2}{*}{ 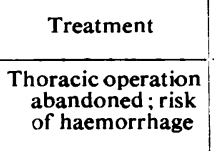 } & \multirow{3}{*}{$\begin{array}{l}\text { Result } \\
\text { No change in tumour } \\
\text { size or patient's } \\
\text { condition } 4 \text { months } \\
\text { later } \\
\text { Died of poliomyelitis }\end{array}$} \\
\hline 1 & $\mathbf{M}$ & 59 & Lattes (1950) & $\begin{array}{l}\text { Essentially intra- } \\
\text { thoracic }\end{array}$ & $\begin{array}{l}\text { Resected cervical } \\
\text { portion } 80 \mathrm{~g} .\end{array}$ & $\begin{array}{l}\text { Swelling in neck } \\
\text { for } 14 \text { years }\end{array}$ & & \\
\hline 2 & $\mathbf{M}$ & 35 & , , , & $\begin{array}{l}\text { Aortic arch body, } \\
\text { one of } 3 \text { tumours }\end{array}$ & $1-2 \mathrm{~cm}$. diameter & At necropsy & 一 & \\
\hline 3 & $\mathbf{M}$ & 22 & Monro (1950) & $\begin{array}{l}\text { Presumed aortico- } \\
\text { pulmonary glomus }\end{array}$ & Not stated & $\begin{array}{l}\text { Biopsy of supra- } \\
\text { clavicular meta- } \\
\text { stasis }\end{array}$ & $\begin{array}{l}X \text {-irradiation (400 } \\
\text { r) to supraclavi- } \\
\text { cular region }\end{array}$ & $\begin{array}{l}\text { Patient deteriorated } \\
\text { over } 3 \text { years; dys- } \\
\text { pnoea and dyspha- } \\
\text { gia; calcified mass } \\
\text { in liver }\end{array}$ \\
\hline 4 & $\mathbf{M}$ & 18 & $\begin{array}{l}\text { Duncan and } \\
\text { McDonald } \\
\text { (1951) }\end{array}$ & $\begin{array}{l}\text { Right costoverte- } \\
\text { bral sulcus }\end{array}$ & $\begin{array}{c}7 \times 5 \times 4 \mathrm{~cm} . \\
50 \mathrm{~g} .\end{array}$ & $\begin{array}{l}\text { Routine chest } \\
\text { radiograph in } \\
\text { Army }\end{array}$ & Operative excision & Well 6 years later \\
\hline 5 & $\mathrm{~F}$ & 33 & , , , & $\begin{array}{l}\text { Right costoverte- } \\
\text { bral sulcus }\end{array}$ & Not stated & $\begin{array}{l}\text { Routine chest } \\
\text { radiograph }\end{array}$ & $\begin{array}{c}\text { Removed at } \\
\text { operation }\end{array}$ & $\begin{array}{l}\text { Vertebral mass and } \\
\text { spastic paraplegia } \\
14 \text { years later; not } \\
\text { biopsied }\end{array}$ \\
\hline 6 & $\mathrm{~F}$ & 67 & $\begin{array}{l}\text { Davies and } \\
\text { Randall } \\
\text { (1954) }\end{array}$ & $\begin{array}{l}\text { Attached to peri- } \\
\text { cardium over } R \text {. } \\
\text { auricle }\end{array}$ & $6 \times 4 \times 3 \mathrm{~cm}$. & At necropsy. & - & $\begin{array}{l}\text { Died of suppurative } \\
\text { bronchitis and } \\
\text { peritonitis }\end{array}$ \\
\hline 7 & $\mathrm{~F}$ & 38 & $\begin{array}{c}\text { McDonald et al. } \\
\text { (1954) }\end{array}$ & $\begin{array}{l}\text { Superior } \\
\text { mediastinum }\end{array}$ & $\begin{array}{l}7 \times 7 \times 3.5 \mathrm{~cm} . \\
70 \mathrm{~g} .\end{array}$ & $\begin{array}{l}\text { Admitted in } \\
\text { labour; routine } \\
\text { chest radiograph }\end{array}$ & $\begin{array}{l}\text { Enucleated at } \\
\text { operation; bleed- } \\
\text { ing troublesome }\end{array}$ & $\begin{array}{l}\text { Discharged well on } \\
5 \text { th post-operative } \\
\text { day; no recurrence } \\
\text { mentioned }\end{array}$ \\
\hline 8 & $\mathbf{M}$ & 79 & $\begin{array}{l}\text { MacDonald } \\
(1956)\end{array}$ & $\begin{array}{l}\text { Around L. Sub- } \\
\text { clavian artery } \\
\text { distal to thyro- } \\
\text { cervical axis }\end{array}$ & $5 \mathrm{~cm}$. diameter & At necropsy & 一 & $\begin{array}{l}\text { Died; oesophageal } \\
\text { varices, haemo- } \\
\text { chromatosis, hepa- } \\
\text { toma, syphilitic } \\
\text { aortic and }\end{array}$ \\
\hline 9 & $\mathbf{M}$ & 7 & $\begin{array}{l}\text { Gillis } e f a l . \\
\quad(1956)\end{array}$ & $\begin{array}{l}\text { On anterolateral } \\
\text { aspect of lower } \\
\text { lobe of right } \\
\text { lung }\end{array}$ & $4 \mathrm{~cm}$. diameter & $\begin{array}{l}\text { Chest radiograph } \\
\text { in investigation } \\
\text { of anorexia, fever, } \\
\text { weight loss, and } \\
\text { pallor }\end{array}$ & 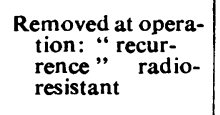 & $\begin{array}{l}\text { Local recurrence } 2 \\
\text { years later; died } \\
\text { shortly afterwards; } \\
\text { no nocropsy }\end{array}$ \\
\hline 10 & $\mathbf{M}$ & 30 & $\begin{array}{l}\text { Shaw and } \\
\text { Kennedy } \\
(1956)\end{array}$ & $\begin{array}{l}\text { 9th left interspace } \\
\text { in paravertebral } \\
\text { gutter }\end{array}$ & $1.0 \times 0.5 \mathrm{~cm}$ & $\begin{array}{l}\text { Routine chest } \\
\text { radiograph; } \\
\text { watched for }\end{array}$ & Operative excision & $\begin{array}{l}\text { Patient well } 10 \\
\text { months later }\end{array}$ \\
\hline 11 & $\mathbf{F}$ & 31 & $\begin{array}{l}\text { Mendelow and } \\
\text { Slobodkin } \\
\text { (1957) }\end{array}$ & $\begin{array}{l}\text { Anterior superior } \\
\text { mediastinum }\end{array}$ & $12 \times 8 \times 5 \mathrm{~cm}$ & $\begin{array}{l}\text { Routine chest } \\
\text { radiograph }\end{array}$ & $\begin{array}{l}\text { Biopsied ; consid- } \\
\text { erable haemor- } \\
\text { rhage; } 2,400 \mathrm{r} \\
\text { given in } 16 \text { doses }\end{array}$ & $\begin{array}{l}\text { Patient's condition } \\
\text { and tumour's radio- } \\
\text { logical appearances } \\
\text { unchanged "during }\end{array}$ \\
\hline 12 & $\mathbf{M}$ & 53 & $\begin{array}{l}\text { Heppleston } \\
\text { (1958) }\end{array}$ & $\begin{array}{l}\text { Periphery of right } \\
\text { lung }\end{array}$ & $4 \times 3 \times 3 \mathrm{~cm}$. & $\begin{array}{l}\text { Routine chest } \\
\text { radiograph; } 6 \\
\text { years increase in } \\
\text { size }\end{array}$ & Operative excision & $\begin{array}{l}\text { No recurrence after } \\
3 \text { years }\end{array}$ \\
\hline 13 & $\mathbf{M}$ & 63 & Barrie (1961) & $\begin{array}{l}\text { Attached to peri- } \\
\text { cardium over } \\
\text { right auricle }\end{array}$ & $3.5 \times 2.5 \therefore 1.5 \mathrm{~cm}$ & At necropsy & - & $\begin{array}{l}\text { Died of virus } \\
\text { pneumonia }\end{array}$ \\
\hline 14 & $\mathbf{F}$ & 51 & , , & Aortic arch body & $7 \times 6 \times 5.5 \mathrm{~cm}$ & $\begin{array}{l}\text { Routine chest } \\
\text { radiograph }\end{array}$ & $\begin{array}{l}\text { Operative excision } \\
\text { without significant } \\
\text { bleeding }\end{array}$ & Well after 12 months \\
\hline
\end{tabular}


state that unnecessarily radical surgery can be avoided if the non-chromaffin paraganglioma is not mistaken for a malignant vascular neoplasm.

Other malignant lesions to be considered are those arising in nervous tissue, primary and secondary tumours of mediastinal lymph nodes, and single pulmonary metastases. Non-neoplastic but space-occupying lesions, such as intrathoracic goitre and aortic aneurysm, come into the differential diagnosis of radiological shadows in this area, while simple tumours to be distinguished include lipoma, fibroma, chondroma, myxoma, dermoid and other cysts, and benign neurogenic tumours. Similar radiological appearances can be produced by a bronchial adenoma, and this may present diagnostic difficulties even under the , microscope ; Heppleston (1958) considered that the intrapulmonary tumour which he reported: could not be distinguished with certainty from a bronchial adenoma of unusual type. This comment prompted a review of the 18 bronchial adenomas recorded in this department since 1947, and in two of these there were certain histological features which resembled those of a nonchromaffin paraganglioma (Figs. 13, 14, 15, and 16). Both these tumours presented as pedunculated growths within large bronchi and in neither instance was there reason to alter the original diagnosis. In this connexion it should be noted that LeCompte (1948), in his discussion on the histological appearance of carotid body tumours, used the expression "adenoma-like" to describe one group of cases. He recognized a "usual type," an "adenoma-like" and an "angioma-like" structure, but felt that in spite of these variations the fundamental pattern appeared to be the same, a group of chief or epithelioid cells surrounded by a more or less abundant vascular stroma.

Histological Features.--Four main features are to be sought in establishing the histological diagnosis of non-chromaffin paraganglioma.

Vascularity.-This is often so intense as to suggest at first glance that the tumour is angiomatous in nature. The blood spaces may be large or small, the walls ill-defined or quite well developed. A peculiar hyaline change around the vessels may be diagnostically helpful but is unexplained; it is not accompanied by ischaemic effects such as cellular degeneration or replacement fibrosis.

Alveolar Structure.-The extent to which this is developed varies. At its greatest, the tumour is divided into large, solid alveoli separated by broad bands of collagen in which run the main blood vessels. Within these alveolar formations the cells are often grouped in clusters of 12 to 20 , and this arrangement is best demonstrated by reticulin staining.

Reticulin Pattern.-Characteristically, the reticulin fibres surround nests of up to a score of cells, but do not pass between the individual components. Often the reticulin strands appear to radiate outwards from the blood vessels, and Gillis, Reynolds, and Merritt (1956) referred to a "basket pattern" produced by the interweaving fibres. This typical arrangement has been found in 12 of the 14 cases listed in Table II, while in the other two reports this technique is not mentioned.

Cell Morphology.-In size and number the predominant cell is polyhedral with pale oxyphilic and finely granular cytoplasm; the borders are often frayed. The nuclei are large, round, or oval, and they stain lightly with basic dyes and have an open chromatin network. In addition to this "epithelioid" cell, Burman (1956) has described smaller cells which are fewer in number but nevertheless quite constant components of these tumours; their most obvious feature is an eccentric, deeply staining nucleus.

No positive chromaffin reaction has been reported in any of the cases reviewed. Haemosiderin pigment was identified in the tumours described by Lattes (1950) and by Mendelow and Slobodkin (1957). Nerve fibres were also noted by Lattes, but Heppleston stated that they were absent from the tumour he examined. No nerve tissue was found in the present cases, the chromaffin reaction was negative, and no intracellular glycogen was demonstrated either by the periodicacid-Schiff reaction or by Best's carmine. Small amounts of haemosiderin were visualized by the Prussian blue method in the first tumour only; the pigment was confined almost entirely to the fibrous septa.

\section{SUMMARY}

Two further cases of intrathoracic tumours of carotid body type are recorded; one was an incidental finding at necropsy in a man aged 62. the other was discovered during a mass miniature radiography campaign and was successfully removed from a woman of 51 years. The relevant details of 12 cases reported in the literature are reviewed, and an account is given of the differential diagnosis of intrathoracic tumours of chemoreceptor tissue, including the radiological, surgical, and histological features. The finding of a second 


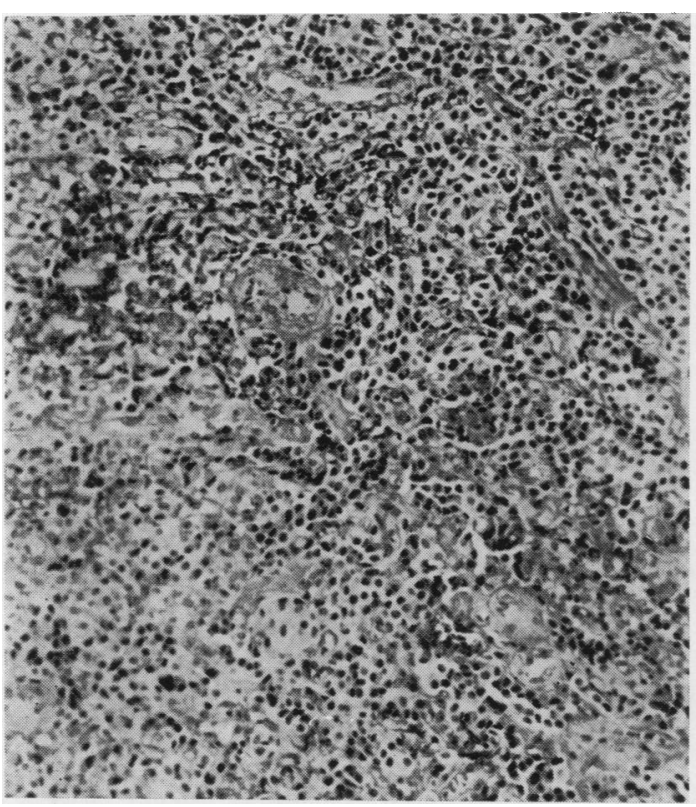

FIG. 13.-Bronchial adenoma. Alveolar pattern and numerous small blood vessels, some showing early hyalinization of their walls. Masson-Goldner, $\times 150$.

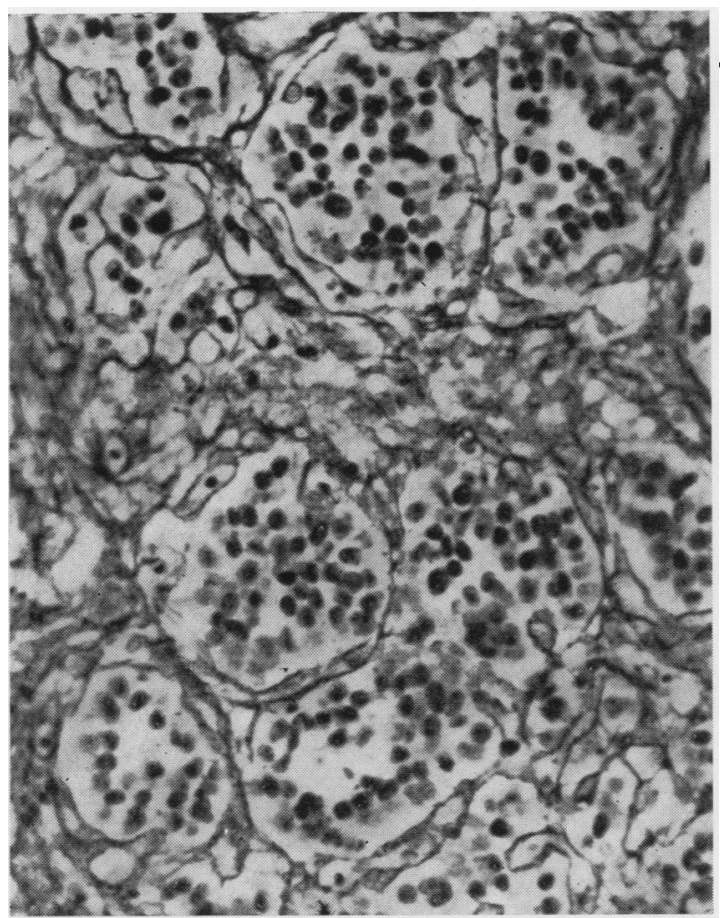

FIG. 14.-Bronchial adenoma. Same case as Fig. 13, showing reticulin pattern. Reticulin, $\times 330$.

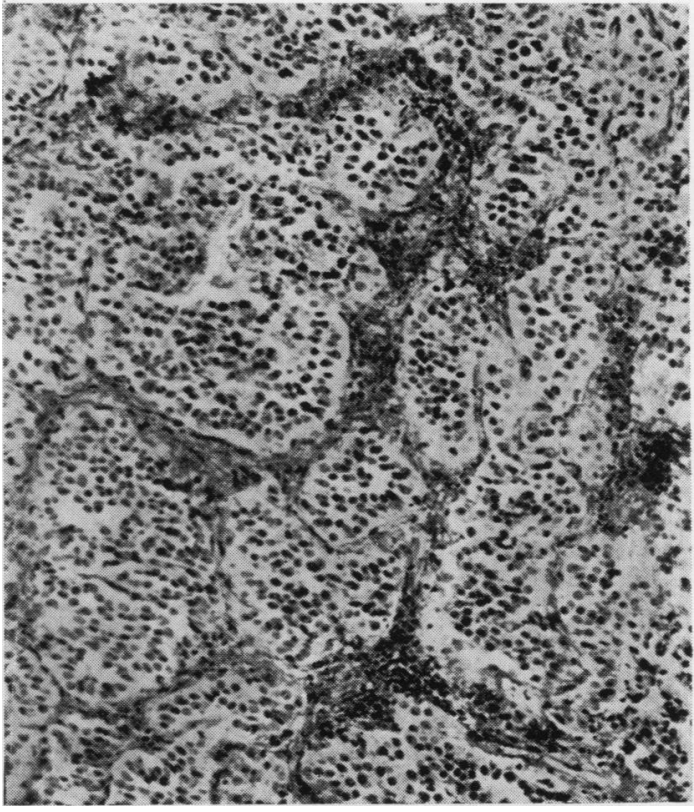

Fig. 15.-Bronchial adenoma. Alveolar pattern and numerous large and small vascular spaces. Masson-Goldner, $\times 150$.

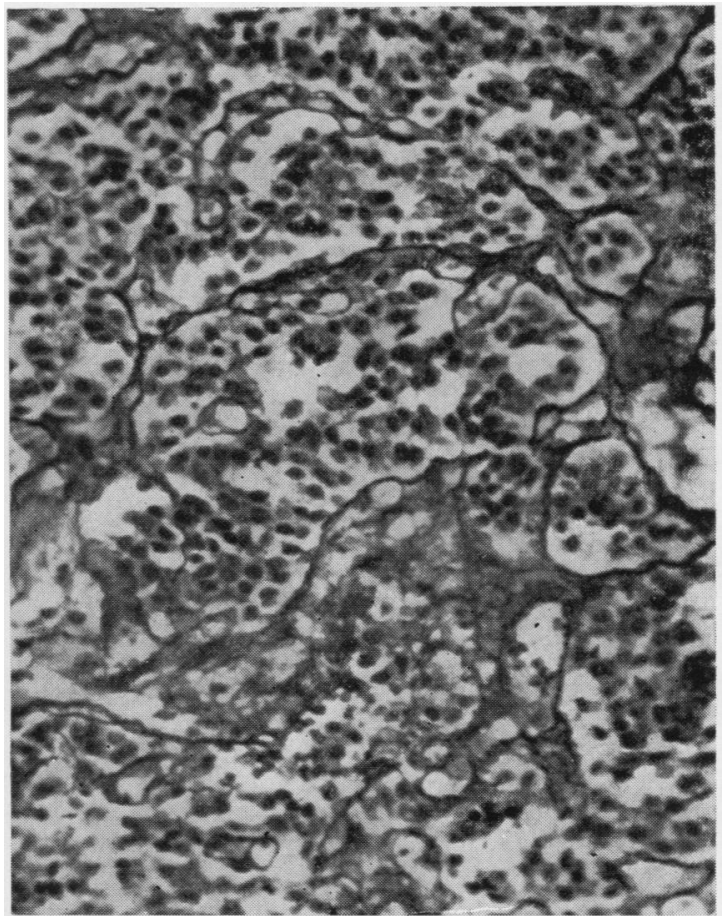

FIG. 16.-Bronchial adenoma. Same case as Fig. 15, showing reticulin pattern. Reticulin, $\times 330$. 
intrapericardial tumour at the base of the heart suggests that this may be a previously unrecognized site of chemoreceptor tissue.

I wish to thank Dr. A. A. F. Peel and Mr. R. S. Barclay, by whom these patients were treated, for permission to publish the clinical details. I am very grateful to Dr. W. B. Davis and Dr. J. E. Craik for their advice on the histology and their encouragement and criticism during the preparation of the manuscript.

I thank the Photographic Department for the illustrations.

\section{REFERENCES}

Burman, S. O. (1956). Int. Abstr. Surg., 102, 330.

Comroe, J. H., and Schmidt, C. F. (1938). Amer. J. Physiol., $121,75$. Davies, J. R., and Randall, K. J. (1954). J. Path. Bact., 68, 247.
Duncan, D. K., and McDonald, J. R. (1951). Amer. J. clin. Path., 21, 515.

Gaffney, J. C. (1953). J. Path. Bact., 66, 157.

Gillis, D. A., Reynolds, D. P., and Merritt, J. W. (1956). Brit. J. Surg., 43, 585

Heppleston, A. G. (1958). J. Path. Bact., 75, 461.

Lattes, R. (1950). Cancer, 3, 667.

— and Waltner, J. G. (1949). Ibid., 2, 447.

LeCompte, P. M. (1948). Amer. J. Path., 24, 305.

(1951). Atlas of Tumor Pathology, Section IV, Fasc. 16. Armed Forces Institute of Pathology, Washington, D.C.

MacDonald, R. A. (1956). A.M.A. Arch. Path., 62, 107.

McDonald, O. G., Aufderheide, A. C., and Fuller, J. (1954). Ann. Surg., 140, 254.

Mendelow, H., and Slobodkin, M. (1957). Cancer, 10, 1008.

Monro, R. S. (1950). Brit. J. Surg., 38, 105.

Mulligan, R. M. (1950). Amer. J. Path., 26, 680.

Schmidt, C. F., Dumke, P. R., and Dripps, R. D., Jr. (1939). Amer. J. Physiol., 128, 1.

Shaw, K. M., and Kennedy, J. D. (1956). Thorax, 11, 57.

Simpson, I. C., and Dallachy, R. (1958). J. Laryng., 72, 194.

Smetana, H. F., and Scott, W. F., Jr. (1951). Milit. Surg., 109, 330.

Willis, R. A. (1953). Pathology of Tumours, 2nd ed., p. 872. Butterworths, London. 